Revista de
Economild
Contemporâned

\title{
TENSIONS BETWEEN THEORY AND HISTORY IN VON MISES'S CRITIQUE OF SOCIALISM
}

\author{
Emmanoel Boff ${ }^{a}$

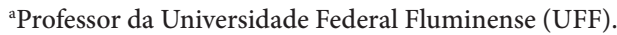 \\ Manuscript received on 2017/06/13 and accepted for publication on 2018/03/13.
}

\begin{abstract}
The article investigates the relation between praxeology and history in the critique Mises directs at the possibility of the long-term existence of a socialist commonwealth. We argue that Mises makes no clear distinction between the praxeological concept of 'private property' (associated with the possession of means of production) and the historical concept of the ideal-type 'private property' (associated to property rights - see HODGSON, 2015). The lack of precision between the theoretical and the historical concepts of private property prevents Mises's critique from being an 'exact law', as he would have it. Finally, we show in the last section the consequences for Mises's critique of socialism of having a historical and a praxeological concept of private property.
\end{abstract}

KEYWORDS: Mises; socialism; socialist calculation; critique.

JEL CODE: B13, B14, B15.

Corresponding Author: Emmanoel Boff

Contact: emmanoelb@gmail.com 


\section{TENSÕES ENTRE TEORIA E HISTÓRIA NA CRÍTICA DE VON MISES AO SOCIALISMO}

RESUMO: O artigo investiga a relação entre a praxeologia e a história na crítica que von Mises dirige à possibilidade da existência de socialismo no longo prazo. Argumentamos que Mises não faz uma distinção clara entre o conceito praxeológico de "propriedade privada" (associado com a posse dos meios de produção) e o conceito histórico do ideal-tipo "propriedade privada" (associado aos direitos de propriedade - ver HODGSON, 2015). Esta falta de precisão entre o conceito teórico e o histórico de propriedade privada faz com que a crítica de Mises ao socialismo não obedeça ao estatuto de uma "lei exata" como ele gostaria. Por fim, mostramos na última seção as consequências para a crítica de Mises ao socialismo de termos um conceito histórico e outro praxeológico de propriedade privada.

PALAVRAS-CHAVE: Mises; socialismo; cálculo socialista; crítica. 


\section{TENSIONS BETWEEN THEORY AND HISTORY IN VON MISES'S CRITIQUE OF SOCIALISM}

Ludwig von Mises, along with F. A. Hayek, can be considered one of the most important Austrian economists of the generation which succeeded Menger, Wieser and BöhmBawerk in the first half of the $20^{\text {th }}$ century. As Rothbard (1991) remarks, Mises's and Hayek's contributions to economic thought are intertwined with the debate of calculation under socialism that began in the 1920's (with Mises's contribution beginning precisely in 1920) and lasts until today ${ }^{1}$, although with different (and more multifarious) emphases.

Nowadays, von Mises has a strong following, both abroad and in Brazil', and his critique of socialism is recognized as not only previous to that of Hayek, but also as more fundamental (HOPPE, 1996) according to some Austrians. The extent to which Mises's contributions to the socialist calculation debate can be 'dehomogenized' from that of Hayek (SALERNO, 1993) needs not to concern us here. The development of the debate and the refutations coming from economists from other schools (such as Marxists and neoclassics) are also not dealt with in this paper. Our objective here is to analyze Mises's critique of socialism in his own terms, following a line of argument begun by Caplan (2004, 2005), but with a different angle: the relation between theory and history throughout Mises's oeuvre. The reason for adopting this angle is the importance Mises himself attributes to history. Most of his followers usually underline the merits of praxeology, not paying much attention to the central role history plays in Mises's writings ${ }^{3}$ - a role, which can be corroborated by the fact that Mises wrote an almost 400-page long opus wholly devoted to Theory and History, published in 1957. In fact, even in his magnum opus Human Action (1949, ch. 2) and in his Epistemological Problems of Economics (1933, ch. 2 and 3 mainly), the methodological problems coming from the relation between theory and history come to the fore. His battle against the members of the German historical school in the 1920's and 1930's may give the impression that Mises downplays the role of history in the development of the social sciences and in the applications of economics, in particular. It is one of the objectives of this paper to show this is not true.

1 See Barbieri (2004) and Albuquerque (2012) for an overview.

2 There is a Mises Institute located in Auburn, Alabama (USA) since 1982, with a branch in Brazil. Since 2012 there has been an annual meeting of Austrian economics in Brazil, organized by the Mises Institute.

3 In the 1985 edition of Mises's Theory and History, Murray Rothbard remarks, in the Preface of the book, how Mises's "last great work (...) has made remarkably little impact, and has rarely been cited even by young economists of the recent Austrial revival". Despite the fact that Rothbard Preface is now 30 years old, no systematic and in-depth investigation of Mises's position regarding the relation between theory and history has been carried out so far, to the best of our knowledge. 
More precisely, the central aim of this paper is to show that Mises's insightful contributions to the relation between theory and history do not spare him from developing a hidden tension (which is not necessarily a contradiction or an inconsistency, as we will explain in section 4) between them. This tension surfaces mainly when he deals with concrete phenomena, as when he criticizes the possibility of the long-term existence of a socialist commonwealth. In other words, the hypothesis put forth by the paper is that the logical chain of argumentation that Mises presents to deduce the impossibility of monetary calculation under a socialist central government rests, firstly, on an ideal-type category ('private property'), in Max Weber's sense, and not on an action category (which could be considered purely logical and not historical). This means that his theoretical deduction rests on a historical concept ('private property'), which makes his deduction contingent and not exact. In the second place, the type of individual action more coherent with the ideal-type 'private property' is purposive-rational action, again in Weber's sense. In other words, actions that Weber classifies as valuational, traditional or emotional (and which Mises reduces to equally rational) do not necessarily cohere with the ideal-type 'private property', contrary to what Mises might have hinted at.

In order to carry out our objectives in the paper, we will structure it in three central sections (plus this Introduction and the Concluding Remarks). In the second section, we will present Mises's view of the relation between theory and history, mainly in his discussion with Weber in chapter 2 of Epistemological Problems of Economics. It will be argued that Mises's methodological discussions are a consequence of problems that were not properly solved in the Methodenstreit of the 1880's. Despite recognizing Weber's contributions to the discipline of history as valid and necessary, Mises clearly demarcates the frontier between history and praxeology, arguing that the latter (as a logical, formal science of human action) should logically precede the former (as a science of the comprehension (Verstehen) of empirical human action). However, without history (which he understands in a Weberian sense) Mises recognizes that praxeology would be only a formal discipline (like mathematics and logic), with little practical significance.

In section three, we will present Mises's critique of socialism, pointing to the fact that his deduction of the impossibility of calculation should be based exclusively in praxeological categories to be theoretically exact. However, that is not the case, because 'private property' is an ideal type. If this argument is correct, then Mises's (praxeo) logical argument against the impossibility of calculation under socialism cannot be said to have a status of an exact law, but of a historical regularity, which can be held true with a certain degree of probability. Moreover, it is not any kind of rational action, which can be associated exactly with the ideal type 'private property': if the action is valuational, emotional or traditional, then it is doubtful whether it is always and everywhere compatible with 'private property'. 
Finally, in section 4, it is suggested that the tension between history and theory identified in the previous sections can be classified and broken down into three mains categories: 'contradiction/inconsistency between historical fact and theoretical explanation' and 'exact theoretical law' are extreme cases, and 'tension between history and theory' is a middle category. This tension will depend on the stretch of historical time under consideration and the institutional changes which are likely to happen therein. For example, if Mises's critique of socialism were confined to the late 1910's and early 1920's, it may be coherent to picture it as constituting an 'exact law'. However, if we move forward many decades into the twenty-first century, institutional changes in the way one conceptualizes 'property' (and its correlates 'property rights' and 'private property') make Mises's critique less likely to hold. In other words, the tension between history and theory increases, so that the passage of historical time weakens the generality of the law.

In the Concluding Remarks and Future Research, we suggest that Mises's case and our results can help illuminate the relationship between markets and socialism, once we understand that the concepts of private and communal property are not only logical, but historical. One usually thinks about capitalism and markets as so closely linked that the abolishing of capitalism would automatically entail the abolishing of markets - one even talks about 'market capitalism', as if markets and capitalism were one and the same. Our contention is that the relationship between markets and capitalism is historical, and not logical. Capitalism cannot survive without markets, sure; but markets can exist without capitalism - in fact, they have existed long before capitalism appeared in late $18^{\text {th }}$ century. Maybe they can also exist beyond capitalism, in the future.

\section{MISES, WEBER AND THE RESOLUTION OF THE METHODENSTREIT}

\subsection{THE AFTERMATH OF THE METHODENSTREIT FOR MISES}

Usually one caricatures the Methodenstreit as a bitter disagreement between the Austrian Carl Menger and the German Gustav von Schmoller in 1883-1884 regarding the proper method of investigation for the social sciences. This 'battle of methods' had also an English version, between the first marginalists (Jevons and Edgeworth) and economists of a more historical bent, like Cliffe Leslie and John Ingram. However, this episode in the history of economic thought was short-lived, since the publication of both Marshall's Principles and John Neville Keynes's treatise on methodology (The Scope and Method of Political Economy) in 1890 apparently separated both sides (the institutional separation happened only in the $20^{\text {th }}$ century). In other words, in less than 
a decade, the proper role for history and theory had apparently been found and there was no need for further discussion - at least in English speaking countries.

Nevertheless, when one reads 1933's Epistemological Problems of Economics by Mises, the impression one gets is rather different. In some of the chapters, it seems that the battle was still raging. "The battle of the proponents of historicism against the nomothetic science of human action was absurd and preposterous", affirms Mises, as if the matter was still in dispute in the 1920's. And, in fact, the publication of the thirdgeneration German historicist Werner Sombart's Die Drei Nationalökonomien, in 1930, was object of a harsh criticism by Mises in chapter 3 of his 1933 book. Of course, by the 1930's, the original formulation of the problem as a simplistic opposition between German historicist induction vs. Austrian abstract deduction had long been abandoned, as Heinz D. Kurtz, in Steedman (1995, ch. 2), observes. A proof of this is the fact that a Conference of German speaking economists, which took place in 1932, in the German city of Dresden, saw a great deal of agreement between historicists and marginalists. This agreement testifies to the overcoming of the initial terms of the Methodenstreit. In 1932, reports Kurtz, both historicists and marginalists could agree that pure theory is important for the development of economic science. Both could also agree on adopting the theory of marginal utility, as a leading figure of the young historical school, Arthur Spiethoff (apud HEINZ, p. 68) declared. The problem then, was no longer a dispute about the proper theory of value, since it seemed that only Marxists and Ricardians clung to the labour theory of value by the 1930's. Yet, it seems that in Mises's 1933 view, the debate was still not over. So what was the problem?

The problem seems to rest in finding generality and universality for the propositions of economics. This point goes beyond the admission that deduction and induction were important for a meaningful economic theory. The important point here seems how to overcome the problem of the historical specificity of the social sciences, as Hodgson (2001) put it. In other words, economics, like any modern science, aims at finding universal laws and general propositions. However, the method a social scientist should use to find these supposed universal laws must be different from the method of the natural sciences. For example, if a chemist identifies and measures the properties of a substance like carbon (e.g., its electronegativity or density), he or she can be sure that this property holds independent of time and space, given certain initial conditions that could, in principle, be controlled in an environment like a laboratory. Unfortunately, the same procedure is not available to the social scientist.

Beginning with Karl Knies (a professor of Max Weber's and member of the older historical school), the problem identified by historicism is that humans are not only biological living beings, but also possess a subjectivity and a culture which changes in time. As a consequence, the 'laws' that govern the behavior of human subjects must 
also change in time, at least to some extent. In other words, the laws that govern the physical world are of a different nature from the 'laws' that govern human behavior. Social objects (e.g., money, interest rates, and governments) depend on the common, shared beliefs of the members of a specific society in order to exist and endure in time. If these shared beliefs change, so can the social objects change. If that is so, there is definitely a problem for the social sciences: in principle, they should, like any other science, aim at universal, general laws. However, the behavior of humans in society cannot be studied like substances in chemistry of physics, be it because they are not amenable to controlled experiments, be it because humans possess a subjectivity that depends on time, space and nationality. The challenge put forth by historicism - and which Mises tries to answer in 1933 - is well put by Knies in the passage below:

In opposition to the absolutism of theory, the historical conception of political economy rests upon the fundamental principle that the theory of political economy, in whatever form we find it, is, like economic life itself, a product of historical development; that it grows and develops in living connection with the whole social organism, out of conditions of time, space and nationality (...) the absolutism of theory (...) exists only as the offspring of time, and marks but a stage in the historical development of political economy (...). (apud PALGRAVE, 2015, p. 277)

Here is, in a nutshell, the tension between theory and history that Mises will find some eight decades after Knies published his book in $1853^{4}$. This passage contrasts well with the Enlightenment progressive and universalist view of knowledge coming from countries like France (Voltaire, Rousseau), Scotland (Smith and Hume) and Germany (from Kant to Hegel). Instead of seeing modernity as the stage where humanity finally found at least the way to reach universal knowledge (which Knies critically defines as the 'absolutism of theory'), the romantic heritage of German economic thought sees this universality as only 'a stage in the historical development' of political economy. Universalism is not the end-point of humanity towards reason, but it is son and heir of a given culture and time. It may change or even disappear in the future. However, if this is true, then we should be skeptical regarding the universality of human behavior. This is precisely the challenge that Mises faces: to find a universal law for the behavior of humans without letting go of the concrete historicity of really existing human societies. But how does he go about this challenge?

4 Die Politische Ökonomie vom Standpunkt der Geschictliche Methode (The Political Economy from the Standpoint of the Historical Method). 


\subsection{MISES'S SOLUTION: THE THEORY OF THE HUMAN ACTION}

First of all - and in order to fend off the menaces of skepticism and relativism - Mises holds on to an unchanging concept of reason - as he puts it, "(...) none of the sources of historical information accessible to us contains anything that could shake the assumption of the immutability of reason" (1933, p. 111). The idea that reason could change in time - be it in a historicist fashion or in a dialectical manner, Hegel-style must be excluded from the start. Reason is the same everywhere and for everyone (disregarding cases of mental disability or the like). This is the anchor to which one should cling in order to find a universal law for the behavior of humans. As one can see, this faith in reason has a Cartesian flavor and, as we will presently see, will also be peppered with a Kantian flavor.

By introducing the central concept of 'action' - more precisely, of rational human action - Mises will try to provide a benchmark whence all the sources of historical information could be assessed and evaluated. One of the contentions that Menger raised against Schmoller in the Methodenstreit was precisely the fact that, without prior theoretical concepts, the data collected by the historian can be organized in many a different corpora, being prone to state logical fallacies and making it difficult to analyze their claims for validity (see HODGSON, 2001, p. 79 and ff.). By saying that humans act, and act purposefully, trying to reach a state of affairs which suits them better than the state of affairs they are at a given moment, Mises effectively proposed a solution to the problem of separating theory and history ${ }^{5}$.

First of all, it must be noted that Mises's concept of action is not only a priori, but also synthetic (here we can see his debt to Kant, as Hoppe (1995, p. 17 and ff.) shows). Therefore, the concept of 'human action' is not attached to any concrete, specific human behavior. In fact - and that is the gist of Mises's Kantian contribution - the concept of action serves as a bridge between the subjective plan of the agents and the causal behavior they exhibit in concrete objective reality. As in Kant's first Critique, the concept of 'human action' works as a schema through which one can fit the whole range of concrete human activities. Using this concept, the actual action of a capitalist entrepreneur who tries to maximize one's profits can be understood as purposeful in the same manner as the action of a revolutionary, which aims to bring down the

\footnotetext{
5 As he puts is: "The laws of sociology [another name for praxeology, for Mises] are neither ideal types nor average types. Rather, they are the expression of what is to be singled out of the fullness and diversity of phenomena from the point of view of the science that aims at the cognition of what is essential and necessary in every instance of human action. (...) They are rather a generalization of the features to be found in the same way in every single instance to which they refer" (1933, p. 98).
} 
capitalist regime. And so is the action of a tribesman who, for example, sacrifices one's physical well-being (or even one's own life) in the name of a god. All of these actions are rational and causal in the sense that they try to move the agents who engage in them from a previous state of affairs A to a more suitable future state of affairs B. Of course, the suitability of the state of affairs B will depend on the actual values of the agent. Therefore, theory gives us the forms in which the historical concrete actions fit. They are separated, but dependent on one another.

Secondly, and because of the fact that human action does not refer to any specific behavior, values are equally separated from the actions necessary to attain these ultimate values. To put it a bit differently, Mises presupposes in his theory that means and ends (values) are also separated. For instance, to sacrifice your own life in a magical ritual or to eat healthy food to prolong your life are different ends whose satisfaction demand different means. The economist investigates how a purposeful agent deploys the available means to attain these ends, and that is pretty much all there is to it. In other words, theory should be neutral regarding the ends of human action. It should be useful to understand the altruistic behavior of Mother Theresa or the greedy behavior of an entrepreneur, or even the choices a violent warlord must make in order to increase one's power. The kinds of values each of them has are absolutely different, but once we know the ends at which each of them is aiming, we can logically deduce - and deduce exactly - the kind of behavior and the means they will deploy. If they, in reality, do not adopt either the behavior or the means deduced by the economist, the historian must come in to help understand which empirical disturbing factors prevented the deduced action to actually take place. In fact, it is only when the historian identifies precisely the values and ends in a given context that the deductions of the economists can be said to hold concretely, instead of only being valid in the abstract ${ }^{6}$.

\subsection{PROBLEMS WITH MISES'S PRAXEOLOGY}

Despite Mises's ambitious claim to have established an a priori theory of human action - which he will call 'sociology' until the mid-1930's and then 'praxeology' until the end of his life ${ }^{7}$ - Mises's theoretical and methodological proposal did not go unchallenged.

6 It is clear in this paragraph how Mises influenced Lionel Robbins's 1932 Essay. However, he always set himself apart from the idea of economics as a mathematical or statistical science (like later neoclassics) or history as something like cliometrics.

7 Notice again that Mises uses until the 1930's the expression 'sociology' to refer to the science that studies purposeful human action, so that Mises's usage of the term has nothing to do with its modern use. Ac- 
We will now present two of the criticisms, which will help us identify more precisely what we mean by 'tension' between history and theory for Mises.

The first criticism comes from Mises's Austrian colleague, F. A. Hayek, but can also be attributed to Marxists and institutionalists. Starting in the 1937 article on Economics and Knowledge and moving to 1943's The Facts of the Social Sciences, Hayek disagrees with Mises regarding the a priori status of the propositions in economics. Hayek concedes that for an acting individual, the praxeological method is indeed sound. When we study the market, however, what we study are not only the actions of isolated individuals, but of interacting ones. If that is the case, the nature of the interaction among the individual changes the pattern of behavior of the aggregate - the market. For Hayek, praxeology stops being a priori the moment it takes into consideration the interactions of individuals. From then on, it must perforce be empirical. Since social interactions constrain and influence the ends individuals go after, it is only by studying these interactions that we will be able to determine how individuals will use means rationally so as to attain their ends.

It is possible to retort to this objection stating that the fact that praxeology studies the behavior of individuals does not mean that this behavior is not influenced by social values and interactions. It is just that the study of values and interactions among individuals is beyond the scope of economics. Mises never denies that values and interactions influence individual behavior. Just as an example, when discussing the theme of history, he says that "an individual is at any instant of his life the product of all the experiences to which his ancestors were exposed plus those to which he himself has so far been exposed" (1957, p. 159). As this passage clarifies, Mises does not think that real individuals are Robinson Crusoe types. His point is that there must be a science to study "human valuations and volitions", from a historical-psychological point of view. He terms this science thymology (1957, ch. 12). History, for its turn, also studies human action: it describes a posteriori "the conditions under which people lived and the way they reacted to these conditions" (1957, p. 159). That individuals interact concretely and, as an emergent property, form collective values which feed back into their actions, is not strange to Mises. What is strange to him is to attribute to economics the investigation of these phenomena.

We can concede this point to Mises, sure. But we may also wonder about the price he pays with this strict separation between economics, history and thymology. Because Mises never used anything like a theory of emergent properties or a variant of 
catastrophe theory $y^{8}$ to account for the emergence (or debacle) of institutions caused by the interactions of purposeful individuals, he seems to face a dilemma:

i) He can either use exclusively a priori pure categories of action (Mises exemplifies them as value, cost, price, wealth, exchange and means of exchange - none of which should refer specifically to concrete economic phenomena ${ }^{9}$ ) to make exact deductions of economic phenomena. This vindicates his separation between history and economics; or

ii) He can use categories that emerge from the interaction of individuals in order to make deductions, categories like markets, governments etc. Because these categories only exist depending on the interaction of individuals, deductions which use them are no longer exact, but subject to a probability. There is a tension between the generality of the propositions of praxeology and the specificity of the description of historical categories. It is as if there were a trade-off between the generality of the theory and the specificity of history.

This tension consists of the second criticism one can level against Mises's praxeological method - and that is how Max Weber sees the problems of abstraction in the social sciences. For the latter, "[t]he more 'general', i.e., the more abstract, the laws, the less they accomplish for the requirements of the causal imputation of individual phenomena and, thereby, indirectly, for the understanding of the meaning of cultural events" (apud MISES, 1933, p. 105). Mises, of course, disagrees: for him, abstract praxeological concepts mirror the structure of the actual actions humans must perform to reach their actual objectives, so they are not far away from concrete reality. In order to reduce the four ideal-types of action Weber constructs (rational, valuational, emotional and traditional) to just purposive-rational action, Mises gives concrete examples of how they all fit his definition of purposeful behavior $(1933$, p. 90 ff.). He shows how people who act out of the intrinsic value of an action, or who traditionally follow the same routine for years or, finally, who act on the basis of

8 It should be clear that Mises does not approve of the import of terms from the natural sciences to the social sciences, as we did just above. Our point, however, serves only to highlight how a higher-order object can emerge from the lower-level interaction of individuals. The properties of this new object may not be reducible to those of the interacting individuals, something that, in our view, should call for a qualification of the universal validity of praxeological propositions.

9 We may also wonder about the extent to which categories like 'wealth' and 'means of exchange' can be classified as a priori. If price, cost, value can arguably be imputed in a universal way to individual actions, the same may not be said of concepts which seem sociohistorical, like wealth and means of exchange. Mises himself gives no justification for the a priorism of these concepts. We will talk more about this problem in the next section. 
emotional impulses all act purposively: they all supposedly try to reach a more suitable state than the one they are in. Therefore, in principle, there should be no difference between these four ideal-typical actions, according to Mises. They are all modulations of the same abstract, a priori concept of human action.

Despite sounding convincing, this argument still raises doubts. The first one concerns what we may call the institutional context in which each of the four idealtype Weberian actions could thrive. Because Weber's investigations are historical, his ideal-types are constructed by means of logically abstracting the most relevant aspects of a great deal of individual phenomena dispersed in history. This is how Weber discovers that some epochs and societies are characterized by more emotional, or valuational, or traditional or rational-purposive behavior. If it is true that an emotional and a purposive-rational action have the same logical structure, it is not clear if they could both be abstracted away from the same social milieu in a historical investigation. As we will try to show in the next section, it is more likely that a purposive-rational action flourish in a market society with well-defined property rights. Again, we can spot here a tension between abstract actions as seen by theory and action as abstracted historically by means of ideal-types.

The second doubt regarding Mises's reduction of Weber's historical ideal-types is related to the status of the means-ends relation in traditional or valuational actions. In both of them, means and ends intermingle, because the objective of the action is not to reach for a more suitable state (say, going from state $A$ to $B$ ), but to keep in the state the agent is already in (staying in A). However, if the agent does not want to move from a less suitable state to a more suitable one, he or she does not act, according to Mises unless one defines action negatively, as making an effort not to move.

If our observations above make sense, the deductions of praxeology are exact only in the case of individual behavior, where the social milieu is taken as given. Whenever history passes and $\backslash$ or there is a change in the social milieu, the deductions of praxeology cannot be said to be exact. This does not mean they are false - however, they cannot claim the status of universality which Mises wanted to give them. The next section will try to show that this is the case with Mises's critique of socialism.

\section{PRAXEOLOGY, HISTORY AND THE CRITIQUE OF SOCIALISM.}

No doubt, many Austrians pride themselves on the achievements of praxeology. Right after the fall of the Berlin Wall, and one year before the disintegration of the USSR, Mises's and Hayek's contributions to the problem of economic calculation in socialism were being lauded as finally proven correct. In the postscript for the 1990 edition of 
Mises's classic The Economic Calculation in the Socialist Commonwealth (henceforth ECSC), Joe Salerno writes that

(...)Ludwig von Mises demonstrates, once and forever, that, under socialist central planning, there are no means of economic calculation and that, therefore, socialist economy itself is 'impossible' ('unmöglich') — not just inefficient or less innovative or conducted without benefit of decentralized knowledge, but really and truly and literally impossible. (1990, p. 49)

Really and truly and literally impossible. These are strong words indeed, if they are correct - and at the beginning of the 1990's they sure must have sounded correct, along with the theory which provided those results. Mises himself put great faith in the achievements of economic theory since Adam Smith's time - in fact, he believed that praxeology was the method actually advanced by economists since the beginning of the $19^{\text {th }}$ century. His point was that praxeology had not been precisely defined until the beginning of the $20^{\text {th }}$ century - and this lack of clarity had paved the way for a lot of misunderstandings and fallacies coming from Marxists, institutionalists and historicists. For example, he criticizes Weber for not recognizing the universal validity of the propositions of praxeology. "The economic principle, the fundamental law of the formation of exchange ratios, the law of returns, the law of population (...) are valid always and everywhere if the conditions assumed by them are given" (1933, p. 92). The question is not only the difficulty in defining the conditions under which the universal laws of economics should hold - something that, in the social realm, should give us enough difficulty. The problem is rather the logical status of economic concepts like 'exchange ratio' or 'returns'. Contrasting with Weber, 'exchange' was certainly a logical concept, an abstraction built from the observation of a myriad of historical cases; in short, it was an ideal-type. As such, it was a limit-concept that could at best be used to causally explain analogous historical facts adequately. That is, an ideal type is neither an efficient nor a final cause. It could not be used as a pure a priori concept, like a mathematical or logical concept; one should consult history to know what an 'exchange' properly means.

Our task in this and the next section is to assess the conditions of the so-called impossibility of socialism, as defined by Mises ${ }^{10}$, exploring the nature of the terms he uses to make his critique: are they really a priori or are they implicitly historical?

${ }^{10}$ Mises characterizes socialism right at the beginning of ECSC (p.1) as the economic organization of a 


\subsection{MISES'S ARGUMENT AGAINST SOCIALISM IN A NUTSHELL}

Mises's argument against the possibility of socialism appears in a few pages at the beginning of chapter 3 of his ECSC. He further developed it with 1922's Socialism, which contains not only the original critique but also a refutation of the supposed inevitability of socialism and the idea of socialism as a moral imperative. As Mises understood it, socialism was not only impossible to be carried out in a large economy, but also represented a real threat to the conquests of modern western civilization. For this reason, Mises's argument as presented in the 1920's is not only logical, but also involves ethical imperative and historical examples. For him, it would be logically and historically possible to show that the capitalistic order is better than the socialistic one - at least for extended, modern societies. For now, let us not dwell in Mises's ethical and historical concerns. He held on to the logical gist of the argument in the following decades; the main difference is that he incorporated and responded to the criticisms of Marxists and neoclassics (see, for example, the final sections of chapter 26 of Human Action). To put it briefly, the argument goes as follows.

Starting with the universal fact that men act purposively, he investigates the kind of purposeful action one might find in a society in which there is no private property of the means of production. If there is no private property of the means of production, there can be no exchange between private owners of these means of production. In other words, it is impossible to find monetary prices for these means of production, since prices cannot reflect their relative scarcity for private agents. As a consequence, it is also impossible to make calculations and attribute to means of production a monetary value. Finally, the last conclusion is that a large economy could not be organized following the rules of a central government.

In other words, once the division of labor reaches a point where no central authority could in principle identify and control the stages of the whole economic process, it would be irrational to try to centralize production, because a centralized bureau of statistics would inevitably fail to calculate relative prices for all the means of production in a large country. Mises inverts the Marxist argument for a temporary centralization and statization of the means of production as presented in part IV of 1875's Critique of the Gotha Program: this centralization would no longer be a step leading to a more organized and just society in a future communism. Quite the contrary: it would lead to a society in which the division of labor would constantly diminish, along with the material and technological progress of society. Without the

of them are delegated to a 'special body' - be it a dictator or a group of people with this function. 
coordination by market prices of people's different plans in an extended economy, people would not be able to purposefully act much beyond their immediate environment. Poverty would increase, and total wealth would decrease. The purposeful action of Marxist socialists like Lenin is shown to be logically fallacious: the costs of centralization would far exceed the benefits, so that its ends would be incompatible with the means proposed to attain it.

Consequently, in order to deepen the progress of civilization, one should hold on the capitalist system, according to Mises. Since capitalism allows the existence of private property, there can be markets for intermediary goods like machines and other means of production. Through the operation of competitive and decentralized markets, the forces of demand and supply would purportedly produce visible prices which would allow for calculation and which, in turn, would reflect the relative scarcity of means of production. A purposeful actor may then coordinate one's plans (albeit usually imperfectly, due to the prevailing uncertainty of a decentralized market economy) with the plans of other purposeful actors of whose ends they know nothing (or very little). Consequently, the apparent chaos of production of capitalism would paradoxically be less chaotic than the production in a socialist commonwealth, which would make more people poorer and the economy less dynamic.

As one can see, Mises's chain of logical deduction uses, as main categories those of 'private property', 'market', 'market prices' (as signals of relative scarcity) and 'calculation'. Central in this chain is the category of 'private property', for it is the starting point of the whole rationale. Can it be considered a praxeological category? Mises is plainly aware that 'private property' is an historical concept. Both in Theory and History and in Human Action he clearly speaks of private property in a historical sense. Just as an example, he admits that "Private property is a human device. It is not sacred. It came into existence in early ages of history, when people with their own power and by their own authority appropriated to themselves what had previously not been anybody's property" (1949, p. 679). He goes on to recognize that this process of appropriation was "arbitrary and violent" in the past. However, the point is not to identify the moment in history when this violent and arbitrary process was contained by the rule of law. The point is to identify a 'catallactic', a priori concept of 'private property'. And, precisely, that is what he does in a passage in Human Action, when he admonishes us (in a section properly called "Private Property") not to confuse the catallactic concept of property rights with its legal concept (p. 650). In our view, this distinction is crucial to the logical status of Mises's deductions and their exactitude. A catallactic category of 'private property' would be a priori, and, therefore, amenable to praxeological analysis. The legal category should be studied a posteriori, by history. 
The question then is to show the extent to which the category of 'private property' can be praxeological. Let us recall that Mises thinks that praxeology begins with individuals, because 'only individuals act'. As we saw, they are not isolated Robinson Crusoes, but purposeful individuals who are influenced by the values of their own societies and their own time. Even so, categories such as 'price,' 'cost' and 'value' can be properly classified as praxeological because they refer to individual actions. The fact that, in reality, they are influenced by historical factors does not diminish their logical status. The historian must tell us what these historical factors are so we should know the types of purposes a given individual, historically situated, might have.

\subsection{THE MEANING OF THE DISTINCTION BETWEEN POSSESSION AND PROPERTY FOR PRAXEOLOGY}

One may wonder, however, if the category of 'private property' is on a par with the categories 'prices', 'costs' or 'value'. If one takes 'private property' to mean 'possession', or the act of acquiring (peacefully or violently) an external object (and the services that it renders) by the acting individual, it seems fine to consider it a praxeological category. In fact, there is evidence that property as possession is hardwired in human individuals, as Stake (2004) shows. In this case, possessing something means to own it and to be capable to dispose of it the way one sees fit. But what about private property as a right that is constituted by the shared intentions and representations of acting agents ${ }^{11}$ ? In this case, it seems hard to hold on to the idea of a purely praxeological 'private property', since its very constitution emerges from an empirical process of interactions between agents, as Hayek would have it. 'Private property' cannot be understood from the action of individuals alone, even if those individuals are influenced by social values. In this case, we must use history to understand how 'private property' emerged. In summary, one cannot always think of 'private property' as a praxeological category because it may be more than possession - it can emerge out of a given historical process of interacting individuals, as we pointed in section 2.3 above.

Sure, an individual alone can mentally 'calculate' the 'price', 'cost' or value of an action, independent of any historical concept. Nevertheless, there is a twist to this argument when private property is understood as emerging historically from agentto-agent relations along with agent-to-external-object relations (that is, relations of

11 The problem of intersubjectivity is not much studied in modern economics (an exception is FULLBROOK, 2003). A good collection of essays that deal with the problem of collective intentionality form an analytical philosophical point of view is that of Schmitt (2003). 
pure possession, which seem to be the ones Mises has in mind). As Hodgson (2014, 2015) has recently explained, in order to differentiate the right of property from possession of an external object (and the services derived whence), we must move beyond the individual level and up to an institutional one.

Moreover, one can argue that, depending on the kind of interaction between purposeful individuals, different kinds of institutions will emerge. It particular, the category of 'private property' is more likely to emerge when individuals act in a purposive-rational, self-interested way. For example, the classic essay by Hirschman (1977) shows how capitalism emerged simultaneously in history with the emergence of the concept of interest understood as a calm and constant passion, which permitted predictability and the economic valuation of actions (here we can see how the widespread use of money in modern societies also emerged). Max Weber's argument in the Protestant Ethic..., despite being of a different nature, can also be interpreted in this light: different shared beliefs (about predestination and the meaning of interest) of acting individuals in protestant sects are one condition for the emergence and consolidation in history of calculative practices and capitalist institutions in Western Europe.

The upshot of the argument in this section is the following: Mises's deduction of the impossibility of calculation under a socialist central government holds only if (i) we understand 'private property' as the possession of physical objects (and of the services that can be derived from $\mathrm{it}^{12}$ ) by individual agents and that this concept does not depend on the shared beliefs of the members of a social group to continue to exist; and (ii) the purposive action of agents is such that their behavior in valuing their actions can be calculated (as the expected or estimate outcome of costs and benefits of an action) and their actions should aim to take them to a more suitable state of affairs different from the one they are in.

If conditions 1 and 2 above do not hold, we cannot say that socialism is really and truly and literally impossible. This result, however, does not mean that it is immediately possible or that Mises is completely off the mark. In order to be possible, a future socialist community would have to develop shared beliefs and material practices regarding the mutual recognition of rules that define a centralized 'communal property' (as opposed to 'private property'). It would also have to find and agree on a common, shared system of calculation of social benefits and costs (beyond that of a Pigou-inspired calculation system that just adds up private benefits and costs to arrive at a 'social' benefit or cost). But these are processes that happen in historical time and

12 See Mises (1949, p. 678). 
produce historical concepts; they are not arrived at by means of praxeological deduction.

As one can see, the double meaning of 'private property' may have impacts on Mises's argument about the possibility of socialism as conceived by him. Our task in the next section is to show what these impacts are in more detail.

\section{CONSEQUENCES OF THE DUALITY OF MEANING OF PRIVATE PROPERTY FOR MISES'S ARGUMENT AGAINST THE POSSIBILITY OF SOCIALISM}

Right after the publication of Mises's Human Action, Murray Rothbard and George Schuller exchanged letters regarding a review of Mises's book by Schuller in the American Economic Review in 1950. The substance of Schuller's critique is related to the application of praxeological laws to historical events. In Schuller's last rejoinder to Rothbard, in 1951, he declares that

acceptance of Mises's stated axioms does not necessarily imply acceptance of the 'principles' or 'applications to reality' which he has drawn from them, even though his logic may be impeccable. When a logical chain grows beyond the limits set by stated assumptions, it uses unstated assumptions. The number of unstated assumptions (axioms, postulates, or other) in Human Action is enormous. (SCHULLER, 1951, p. 188)

Schuller goes on to challenge Mises to rewrite his books in a formal way, using axioms and postulates. None of Mises's followers has ever tried to do this, to our knowledge, even though that might greatly simplify the central message of the 900page strong Human Action. And, in fact, we would add that it is impossible to carry out this simplification, because, as we put in section 2.2, and as Schuller makes it clear in the passage above, there are numerous "unstated assumptions" in Human Action. Our own contribution to the debate lies in trying to show that these "unstated assumptions" do not always refer to praxeological categories, but sometimes to ideal-typical ones. If we are right, then it would be impossible to logically exhaust the theses of Human Action in axiomatic form, since ideal-types are logical constructions made out of historical material.

In order to organize the results of our investigation, we will present them in two separate subsections: one that details the consequences for socialism of a praxeological concept of private (and communal) property, and another showing the consequences for socialism of a historical, ideal-type concept of private (and communal) property. 


\subsection{CONSEQUENCES FOR SOCIALISM IN A PRAXEOLOGICAL APPROACH: IMPOSSIBILITY}

As in a central planned socialism 'one will alone acts' - the dictator, according to Mises - and as we assume one physically possesses all means of productions, we can understand one's action praxeologically. In chapter 15 of Socialism, Mises studies particular forms of socialism, admitting that the dictator need not act based exclusively on a purposive-rational basis: the dictator may be the leader of a military socialist commonwealth, a state socialist commonwealth, a Christian socialist commonwealth and so forth. In all cases, however, the use of praxeology is legitimate, since the action of the dictator can be understood as trying to reach a more suitable state starting from a less suitable one. As we have seen, the fact that the dictator has different ends in sight does not hamper Mises's rationale for the failure of socialism presented in section 2.2. In all cases it would be impossible to calculate market prices with dire consequences for the commonwealth.

By the same token, if I have private property (understood as possession), then the acts of individuals obey a praxeological deduction: we have markets for means of production, which have prices and which further the division of labor, making society progress. It is true that, if we have other types of action (emotional, valuational or traditional, associated with other kinds of values), we may not further the division of labor and have progress as much as we would have with a purposive-rational action. But in any case we will have markets, to a greater or lesser extent, and they will give people signs they need (in the form of prices, broadly conceived) in order to make the choices according to their different values.

The situation is different, however, if we associate property not with physical possession but with property rights.

\subsection{CONSEQUENCES FOR SOCIALISM IN A HISTORICAL APPROACH: POSSIBILITIES}

The historical, ideal-typical concept of property presents a more interesting case, as it highlights the fact that property rights centrally owned depend on the shared, intersubjective beliefs and practices of the members of community. This consequence echoes the relatively recent debate between Caplan (2002, 2005), Leeson and Boettke (2005) and Gonzalez and Stringham (2005). Caplan's (2005) argument is that socialism did not fail empirically because of the impossibility of calculation, but because it could not align the incentives of individuals and those of the commonwealth. In fact, if we have (i) individuals who behave in a rational-purposive way; (ii) advances in technologies of calculation \computation that allow for the processing of necessary information about technology and tastes; and (iii) a shared and relatively stable metric for measuring social 
and individual costs, socialism should be, in principle, possible $\mathrm{e}^{13}$. The situation is not so likely if people behave in an emotional way or if ends and means are mixed, as is the case with valuational or traditional actions (see section 2.3 above for our argument). In this case, the investigation should combine a careful analysis of categories: some of them are properly praxeological; others should work as ideal types. As we defended in the Introduction, if we analyze long periods of time or if the institutional context is changing, then the deductions we make are growingly less likely to actually occur.

Reviewing the recent debate on 'market socialism', Albuquerque (2012, ch. 6.3) points to the fact that socialism is not necessarily incompatible either with a stock exchange and small private firms (in the proposal of Roemer) or with self-managed firms, not unlike cooperatives (in the proposal of Bowles and Gintis) or still Burczak's concept of a stakeholder society. It is not our purpose to discuss in detail any of these proposals, but to point to the fact that they are compatible with the existence of markets. If this is true, then we can have socialism and markets for intermediary goods ${ }^{14}$. Private property and socialism are no longer exclusive terms because private property can be an ideal-type, and not a praxeological category. Our deductions are not sure fire as they might be if we only operated with logical concepts, but they gain in practical and historical accuracy. Of course, depending on the types of actions of private agents, the alignment of private and public incentives may be harder to achieve - people that are moved mainly by emotions may lead to unstable institutions, for example. But the central point is that market and socialism (as Mises understood it) need not be seen as incompatible bedfellows, as they were during most of the $20^{\text {th }}$ century ${ }^{15}$.

${ }_{13}$ That is roughly the point of Lange and Taylor (1938) demonstration of the possibility of calculation in a socialist commonwealth using a Walrasian model. However, what has not been stressed in their Walrasian demonstration is the concrete difficulty in finding an adequate technology of computation and a shared and stable metric for measuring social and private costs and benefits. This difficulty must be dealt within an institutional and historical approach, in our view, to be able to identify the institutional framework which can uphold this capacity of computation and of sharing a stable metric.

${ }^{14}$ It is noteworthy that, in a 1926 article on Interventionism, Mises admits that nationalization may not be considered intervention if it does not interfere with the operation of the market by coercing the producer to charge more or less for the product being offered (p. 19). Maybe Mises is hinting at the idea that incentives to act in the market do not have a straight relation to property rights, as Caplan shows.

${ }^{15}$ Corporatism may be a historical example of the combination of communal property of (some) means of production by a central authority and the functioning of markets. This is what happened (in different degrees) in the regime of Park Chung Hee (1962-1979), in South Korea, the Japanese model before 1973 and the nazi and fascist regimes. 


\section{CONCLUDING REMARKS AND FUTURE RESEARCH}

Marx may have identified the laws of tendency which would lead us to the end of capitalism, but gave us only sparse, fragmentary clues about what a future socialist (or even communist) society would look like. It is the merit of Mises to try to imagine what a future socialist society would look like. It is also worthy of merit that he tried to present his ideas in a logical, coherent way, always attentive to the proper method of investigation in the social sciences, and always aiming at general and universal knowledge about human action. Finally, it is equally praiseworthy the fact that he recognized the importance of history (in a Weberian sense) in the development of the social sciences. As he put it, "no sociologist can do without history, and no historian can do without sociology" (1933, p. 116).

However, his claims about the impossibility of socialism seem overrated, in our view. It is not true that "socialism is really and truly and literally impossible" - and we tried to demonstrate the error in this observation using Mises's own terms regarding the importance of theory and history. There are not many academic investigations regarding the relation between theory and history in Mises. Our central claim in the paper is that Mises does not differentiate clearly between praxeological and idealtypical concepts. As a consequence, a tension between praxeological theory and historical ideal-types appear: deductions which are taken as 'exact' find no confirmation in history, and concepts that are historically constructed - private property associated with property rights being the most important for our argument - are taken as purely logical. We tried to disentangle the possible confusion regarding the concept of 'private property', showing that when this concept is historical, Mises's logical deduction does not hold with certainty. We also presented the details of our argument, trying to separate the wheat from the chaff in Mises's praxeological claims. In this way, we can understand George Schuller's complaint in section 4 about the supposed empirical exactitude of Mises's logical deductions.

Finally, and contrary to the usual estrangement which characterizes the Austrian and Marxist traditions, we tried to point to some possible future avenues of research regarding the possible role of private property (historically and theoretically construed) in a socialist community. In our view, the usefulness of such discussion is to be able to think of socialism as a system that does not necessarily exclude markets. As we hinted at in the introduction, the view that socialism and markets are incompatible is usually linked to the view that capitalism and markets as so closely linked that the abolishing 
of capitalism would automatically entail the abolition of markets ${ }^{16}$. However, even if we think of socialism as the Aufhebung of capitalism, that might not necessarily exclude markets - remember that one of the meanings of Aufheben is to keep, to save - so that the overcoming of capitalism might keep markets functioning (although in a different way). As we said, capitalism cannot survive without markets, sure; but markets can exist without capitalism - in fact, they have existed long before it.

\section{REFERENCES}

ALBUQUERQUE, E. M. Agenda Rosdolsky. Belo Horizonte: Ed. UFMG, 2012.

BARBIERI, F. História do debate do cálculo econômico socialista. Tese (Doutorado em Teoria Econômica) - Faculdade de Economia e Administração, Universidade de São Paulo, São Paulo, 2005.

BOETTKE, P.; LEESON, P. Still impossible after all these years: reply to Caplan. Critical Review, v. 17, n. 1-2, p. 155-170, 2008.

CAPLAN, B. Is socialism really 'impossible'? Critical Review, v. 16, n. 1, p. 33-52, 2004.

CAPLAN, B. Towards a New Consensus on the economics of socialism: rejoinder to my critics. Critical Review, v. 17, n. 1, p. 203-220, 2005.

FULLBROOK, E. (Ed.). Intersubjectivity in economics: agents and structures. New York: Routledge, 2001.

GONZALEZ, R.; STRINGHAM, E. Incentives vs. knowledge: reply to Caplan. Critical Review, v. 17, n. 1-2, p. 177-2020, 2005.

HAYEK, F. A. Economics and knowledge. Economica, February 1937.

HAYEK, F. A. The facts of social sciences. Ethics, v. 54, n. 1, October 1943.

HIRSCHMAN, A. The passions and interests. Political arguments for capitalism before its triumph. Princeton: Princeton University Press.

HOPPE, H. H. Economic science and the Austrian method. Auburn: Mises Institute, 1995.

HOPPE, H. H. Socialism: a knowledge or property problem? Review of Austrian Economics, 1996, v. 9, n. 1, p. 147-154.

HODGSON, G. How economics forgot history: the problem of historical specificity in social science. London: Routledge, 2001.

16 We believe this view is probably due to Marx's analysis of the fetishism of the commodity at the beginning of Capital. We cannot develop this idea here, but we can understand that Marx's analysis of the commodity is carried out already with a view to understanding the role of markets within capitalism. In fact, at the very beginning of the volume I of Capital he says that there should also be a science of commodities, dealing with their use values and independent of capitalism. 
HODGSON, G. The economics of property rights' is about neither property nor rights. Working Paper, University of Hertfordshire, 2014.

HODGSON, G. Conceptualizing capitalism: institutions, evolution, future. Chicago: UC Press, 2015.

KURTZ, H. "Marginalism, classicism and socialism in German-speaking countries - 18711932". In: STEEDMAN, I. Socialism and marginalism in economics 1870-1930. London: Routledge, 1995.

LANGE, O.; TAYLOR, F. On the economic theory of socialism (government control and economic order). Minnesota: University of Minnesota Press, 1938.

MISES, L. The economic calculation in a socialist commonwealth. Auburn: Ludwig von Mises Institute, 1990 [1920].

MISES, L. Socialism: an economic and sociological analysis. 3. ed. New Haven: Yale University Press, 1962 [1922].

MISES, L. Epistemological problems of economics. Auburn: Ludwig von Mises Institute, 2003 [1933].

MISES, L. Human action: a treatise on economics. The Scholar's Edition. Auburn: Ludwigvon Mises Institute, 1998 [1949].

MISES, L. Theory and history: an interpretation of social and economic evolution. With a new preface by Murray N. Rothbard. Auburn: Ludwig von Mises, 1985 [1957].

MISES, L. Interventionism: an economic analysis. Auburn: Ludwig von Mises Institute, 2003 [1926].

PALGRAVE, R. H. Dictionary of political economy. Vol. 3. Cambridge: Cambridge University Press, 2015.

ROTHBARD, M. The end of socialism and the calculation debate revisited. Review of Austrian Economics, 1991.

SALERNO, J. Mises and Hayek dehomogeneized. The Review of Austrian Economics, v. 6, n. 2, 1993, p. 113-146.

SCHMITT, F. Socializing metaphysics: the nature of social reality. New York: Rowman and Littlefield, 2003.

SCHULLER, G. Mises's 'human action': rejoinder. American Economic Review, v. 41, n. 1, p. 185190, 1951.

STAKE, J. F. The property instinct. Articles by Maurer Faculty, n. 222, 2004. Available at: <https://www.repository.law.indiana.edu/facpub/222>. Access: 14 June 2018. 